\title{
The Effectiveness of Problem Based Learning (PBL) Method in Teaching Reading
}

\author{
1 Ahmad Zuhri Rosyidi \\ 1Mataram University, Mataram, Indonesia \\ ahmadzuhrirosyid@gmail.com
}

\begin{tabular}{|c|c|}
\hline Article Info & Abstract \\
\hline $\begin{array}{l}\text { Article History } \\
\text { Received: July 12, } 2018 \\
\text { Accepted: September 30, } \\
2018\end{array}$ & \multirow{2}{*}{$\begin{array}{l}\text { This pre-experimental research aimed to find out the effectiveness of } \\
\text { problem based learning in teaching narrative type of reading text at the } \\
\text { tenth grade of public senior high school (SMAN) } 1 \text { Sukamulia, East Lombok. } \\
\text { The sample of this research consisted of } 30 \text { students taken through purposive } \\
\text { sampling. A pre-test and a post-test were used to collect the data on the } \\
\text { reading ability of the students, and observation list was employed to gather } \\
\text { the data on how problem based learning involves the students in the learning } \\
\text { process. The collected data were then analyzed using descriptive statistic } \\
\text { and paired-sample t-test to answer the hypothesis. The result of data } \\
\text { analysis revealed that there was a significant difference between the pre-test } \\
\text { and the post-test scores, } t(d f=29)=5.203 \text { at p }=0.00 \text {, meaning that the null } \\
\text { hypothesis is rejected (Ho) and alternative hypothesis is accepted (Ha).It } \\
\text { means that there was a significant effect of problem based learning method } \\
\text { in teaching critical reading for the tenth graders of SMAN } 1 \text { Sukamulia. }\end{array}$} \\
\hline $\begin{array}{l}\text { Keywords } \\
\text { Problem based learning, } \\
\text { reading, pre-experimental }\end{array}$ & \\
\hline $\begin{array}{l}\text { Support by: } \\
\text { dol Crossref }\end{array}$ & \\
\hline
\end{tabular}

\section{INTRODUCTION}

Reading is one of the language skills which help students in the process of learning English. In teaching and learning English, we usually find students difficulties in reading English text, because they do not read the text only, but they are required to understand the contents of reading materials such as; find out the topic, theme, main idea, and answer the question that related with the text, they are required to have adequate knowledge of language which has different system, including vocabulary and structure. It was happened also to the tenth graders of SMAN 1 Sukamulia. Starting from the problem, this paper is initiative for finding out the alternative method to solve the problem.

To improve their reading skills, languages teacher should use meaningful reading materials and assess the teaching process properly. To assess reading skills, teacher should use materials appropriate to reading basic competence and purpose of the text.

Reading activity has important role in language learning, in that sense of teaching reading, the teacher should consider among others likes; facilities, students' background knowledge and method. To understand a text, student must have good understanding on vocabulary in the target language, as learning a language does not mean merely learning word. Vocabulary proficiently will enable the student to acquire the skills of listening, speaking, reading, and writing.

Kennedy (1997, p.16) argue that "reading is defined as a process of deriving meaning from connected text". It involves word knowledge (vocabulary) as well as thinking and reasoning". Anderson in Karbalaei noticed $(2010$, p. 1), reading is the interaction of four things including the reader, the text, the fluent reading or the ability 
or read at an appropriate rate with adequate comprehension, and strategic reading, or the ability of the reader to use a variety of reading strategies to accomplish a purpose for reading.

Therefore, according to Smith (2004, p.68). Reading is the "acquisition of information" from text or, even more specifically, that reading is a matter of receiving particular messages or facts put into a text by the writer. Furthermore, According to Hibbard \&Wagner (2003, p.1) Reading is a complex behavior including decoding words, developing fluency, and improving comprehension. Another definition, Reading is an active process of constructing meaning; those who understand the process best librarians, reading specialists, and teachers must make explicit and active what good readers do subconsciously and internally (Grimes, 2006:18).

Based on the statement above the present researcher got conclusion that reading is process of constructing meaning that including decoding words, developing fluency, improving comprehension, problem solving, and decision making strategic reading, or the ability of the reader to use a variety of reading strategies to accomplish a purpose for reading.

One of the methods that can be used to help the student's problem in reading is problem based learning. PBL is an instructional method in which students learn through solving problem and reflecting on their experiences (Barrows \&HmeloSilver,2006, P.21). In PBL, the teacher's role is to facilitate collaborative knowledge construction. PBL is a learning approach that uses real-world problems as a context for learners to learn about critical thinking and problem-solving skills, and to acquire essential knowledge and concepts from course or subject matter materials (Sudarman. 2007).

The PBL method requires students to become responsible for their own learning. In PBL teacher is a facilitator of student learning, and his/her interventions diminish as students progressively take on responsibility for their own learning processes. This method is characteristically carried out in small, facilitated groups and takes advantage of the social aspect of learning through discussion, problem solving, and study with peers.

\section{Characteristics of PBL}

Based on the theory developed by Barrow, Min Liu (2005) describes the characteristics of PBL, those are:

1. Learning is student- centred

The learning process in PBL focuses more on students as people learn. Therefore, PBL is supported also by constructivism theory where students are encouraged to be able to develop their own knowledge.

2. Authentic problems form the organizing focus for learning

The problem presented to students is an authentic problem so that students are able to easily understand the problem and can apply it in their professional life later.

3. New information is acquired through self-directed learning

In the process of problem solving, students may not know and understand all the prerequisite knowledge, so that students try to find their own through the source, either from books or other information.

4. Learning occurs in small groups

In order for scientific interaction and exchange of ideas in a collaborative effort to build knowledge, PBL is implemented in small groups. The group created demands clear division of tasks and clear goal setting.

5. Teachers act as facilitators. 
In PBL implementation, teachers only act as facilitators. However, even so teachers should always monitor the development of student activities and encourage students to achieve targets to be achieved.

\section{Procedure of PBL}

Learning situation in the method of problem based learning is logically structured by Ibrahim in wulandari (2016) . It consists of five steps which are presented on Tabel 2.1:

\section{Stages of Problem Based Learning Mode}

\begin{tabular}{|l|l|}
\hline \multicolumn{1}{|c|}{ Stage } & \multicolumn{1}{|c|}{ Teacher role } \\
\hline $\begin{array}{l}\text { Stage }-1 \\
\text { Orientation }\end{array}$ & $\begin{array}{l}\text { The teacher explains the learning objectives, and } \\
\text { explains the possible material needed, and motivates } \\
\text { students to be involved in solving the problems they } \\
\text { choose. }\end{array}$ \\
\hline $\begin{array}{l}\text { Stage }-2 \\
\text { Organizing students to learn }\end{array}$ & $\begin{array}{l}\text { The teacher helps students define and organize learning } \\
\text { activities related to the problem. }\end{array}$ \\
\hline $\begin{array}{l}\text { Stage }-3 \\
\text { Guiding individual and } \\
\text { group inquiries }\end{array}$ & $\begin{array}{l}\text { The teacher tells students to gather appropriate } \\
\text { information, carry out observations / experiments to get } \\
\text { explanation and problem solving. }\end{array}$ \\
\hline $\begin{array}{l}\text { Stage }-4 \\
\text { Developing and presenting the } \\
\text { work }\end{array}$ & $\begin{array}{l}\text { The teacher helps students in planning and preparing } \\
\text { appropriate works such as reports, stories and text } \\
\text { models that help them to share assignments with their } \\
\text { friends. }\end{array}$ \\
\hline $\begin{array}{l}\text { Stage }-5 \\
\text { Analyzing and evaluating } \\
\text { the problem solving } \\
\text { process }\end{array}$ & $\begin{array}{l}\text { The teacher helps students to reflect or evaluate their } \\
\text { investigations and the processes they use. }\end{array}$ \\
\hline
\end{tabular}

According to Gultom in Wulandari (2016) noticed that the advantages of problembased learning are to create learning becomes meaningful. Students who learn to solve a problem then they will apply their knowledge or try to find out the knowledge needed. Learning can be more meaningful and can be expanded when students are faced with situations where the concept is applied. On the other hand, students can integrate knowledge and skills simultaneously and apply them in relevant contexts. Problembased learning can improve the ability to think critically, foster student initiative in work, internal motivation to learn and can develop interpersonal relationships in group work.

In order to encourage the students to critic in reading text interactively, English teachers should provide an interesting method that can improve students' reading achievement so they become an active learners. PBL was well suited to help students become active learners because it made situation of learning in real-world problems and made students' responsible for their learning. Starting from the statement above present researcher decided to investigate the effectiveness of problem based learning method in reading at the Tenth graders of SMAN 1 Sukamulia.

Relating to the background stated previously, the present researcher formulated the main problems: Is Problem based learning method effective in teaching critical reading at the tenth graders of SMAN 1 Sukamulia? and To what extent is the effectiveness of Problem Based Learning method in Reading at the tenth graders of SMAN 1 Sukamulia?

\section{METHOD}

The target population of this study was the entire tenth grade students of SMAN 1 Sukamulia which consists of 6 classes and the number of the population of this study 
were 193 students. Sample of this study was X IPA2 .In this class there was 30 students and to take the sample the present researcher used purposive sampling technique to take it because the present researcher has known the class has good competence.

In collecting the data of this research, we use instrument reading. Instrument is a tool which is used for collecting data. In this research, the present researcher used the test namely a reading test, which was taken from the tenth graders of senior high school book and kind of the test was multiple choices. The test consisted of 35 questions. It was divided into three parts those are five tests is easy test, five tests again was medium and the last five tests was hard. The test was given to sample and the result was collected as the data of this research.

The Technique of Data Collection of this research is the present researcher took the data from pre-test and post-test. Pre-test was given to the subjects before doing teaching and learning process by using traditional method. Meanwhile, post-test was given after doing teaching and learning process by using problem based learning method.

The steps are used to find out the data as follows:

a. The Pre-Test

The first step to collect the data was the present researcher gave the students pretest. This pre-test was aimed at knowing students' reading ability. The pre-test was held by the present researcher in experimental class.

b. Treatment

In treatment part the present researcher treated the students by applying Problem Based learning. The treatments have been done in three meetings.

c. The Post-Test

At the end of gathering data, the present researcher hold post-test. The post test was aimed to know the improvement of students' reading ability after giving treatment.

In analyzing the data, the data of this study were analyzed by using descriptive statistic and inferential analysis. Descriptive analysis was used to know the mean, median, mode, and standard deviation of students' scores in reading test. Inferential analysis was used to know normality and homogeneity previously before the t-test. Normality test was conducted in order to know whether the sample distributed normally or not, while homogeneity test is aimed to know whether the data are homogeneous or not. For this purpose, the researcher performed Frequencies using SPSS 17 for windows.

There are two statistics required before testing hypothesis; those are normal distribution test and homogeneity test which were analyzed by using SPSS Statistics 17 for Windows. First, normality testing was used to know whether or not the data has normal distribution. To know the data was normal or not, the researcher was showed by One-Sample K-S using SPSS 17 for windows, and the second homogeneity test was conducted of this research to know whether the obtained data of the sample was homogenous or not. Homogeneity testing was showed by One-Way ANOVA using SPSS 17 for windows.

\section{RESULTS}

In this part, present researcher presents the description about the students' reading for the tenth graders of SMAN 1 Sukamulia after following the pre-test, treatment, and post-test. In collecting the data, the present researcher used multiple choice texts. To know the students' prior ability in reading; the present researcher gave the pre-test. 
After pre-test was done, problem based learning conducted during teaching and learning process. At the end of the research, the present researcher gave post-test to know the students' achievement after following the treatment.

In this case, the researcher describes the answer of statement of problems: (1) Problem based learning was effective in reading of narrative text for the tenth graders of SMAN 1 Sukamulia? (2) To what extent was the effectiveness of problem based learning in critical reading of narrative text for the tenth graders of SMAN 1 Sukamulia?

Referring to the data gained in pre-test, the result of students as follows: Standard Deviation of pre-test was 11.97 and post-test were 19.87. The lowest and the highest score of pre-test were 35 and 80, while in the post-test obtained the lowest and the highest score of post-test were 35 and 100. In addition, the mean score of pre-test was 61.50 while in post-test was 75.00. The mean scores of post-test was higher than the mean scores of pre-test, it intended that the problem based learning has an effective in teaching reading.

In the normality test by using One-Sample K-S test (SPSS 17 for windows), the result of Kolmogorov-Smirnov showed that the pre-test and post-test were higher than the values of the significance $(\mathrm{p})=0.05$. The value of Kolmogorov-Smirnov in the pre-test was 1.248 and 0.730 in the post-test. The values of the Asymp Sign (2-tailed) were 0.089 for pre-test and 0,660 in the post-test. Those all values were higher than the 2tailed at 0.05 . It means that the data was gained were has normal distribution.

The homogeneity test was calculated by using One-Way ANOVA test. It was used to find out whether the data was homogenous or not. Respectively, the value of Levene's Statistic was 1.982 at $p=0.143$. The value of $p=0.143$ was greater than 0.05 ; it implied that the data were homogenous.

Testing hypothesis was conducted to know whether null hypothesis was accepted or rejected. To analyze whether there was a significant difference in the mean score between the pre-test and the post-test, the present researcher used a paired-samples ttest to get answer of the hypothesis. After performing a paired-samples t-test, the present researcher found that there was a significant difference in the scores between the pre-test and the post-test, $t(d f=29)=5.203$ at $p=0.000$, meaning that the null hypothesis was rejected and alternative hypothesis was accepted. It meant that there was the effective of Problem based learning in teaching reading for the tenth graders of SMAN 1 Sukamulia.

Related to explanation above, the researcher was found out result of this research. The following obtain the data of this investigation, this research used reading test. In this research, the data as the scores of the test 30 students were tested. Observing the mean score of the 30 students from pre test is 61.50. From this result, it can be judged that the tenth grade of SMAN 1 Sukamulia have problem in reading text. The result of the study the students highest score was 75 and lowest was 35. After treatment the researcher found the mean score of post test is 75.00 . The result of the study the students highest score was 100 and lowest was 35.

This finding supports the theory of Barrow \& Hmlo-silver (2006, p.21) they said that Problem Based Learning is an instructional method in which students learn through solving problem and reflecting on their experiences. In PBL teacher is a facilitator of student learning, and the students take on responsibility for their own learning processes. Besides that this method is characteristically carried out in small, facilitated groups and takes advantage of the social aspect of learning through discussion, problem solving, and study with peers. 


\section{CONCLUTION}

Referring the result and discussion of the study, the present researcher concludes that: (1) There was an effectiveness of Problem based learning in teaching critical reading for the tenth graders of SMAN 1 Sukamulia. It can be seen from the result at research that post-test was higher than pre-test, the mean score of pre-test was (61.50) and post test was (75.00). and (2) There was a significant difference in the mean scores between the pre-test and the post-test, $t(d f=29)=5.203$ at $p=0.000$. It means that the null hypothesis was rejected and alternative hypothesis was accepted.

\section{REFERENCES}

[1] Grimes Sharon (2006) Reading is our business, American Library Association Chicago.

[2] Hmelo-Silver E. Hmelo-Silver \& Barrows S. Howard (2006) Goals and Strategies of a Problem-based Learning Facilitator. Published online: 5-22-2006.

[3] Karbalaei, Alireza. (2010) A Comparison of the Metacognitive Reading Strategies Used by EFL and ESL Readers. Mysore University India. Published Journal.

[4] Kennedy Eddie, C. (1977). Methods in Teaching Developmental Reading, Second Edition. California.

[5] Liu, Min. (2005). Motivating Students Through Problem-based Learning. University of Texas : Austin. [online]. Tersedia : http:// [22-03-2007]

[6] Smith, Frank. (2004) understanding of reading Lawrence Erlbaum As Sociates, publishers mahwah, new Jersey London

[7] Sudarman. (2007). Problem Based Learning: Suatu Model Pembelajaran untuk Mengembangkan dan Meningkatkan Kemampuan Memecahkan Masalah. Jurnal Pendidikan Inovatif. 2(2): 68-73.

[8] Hibbard Michael K. \& Wagner A. Elizabeth (2003) Assessing and Teaching Reading Assessing and Teaching Reading Comprehension and Writing, 3-5, Taylor \& Francis.

[9] Wulandari .Y (2016). Penerapan model Pembelajaran Berbasis Masalah Terhadap Kemampuan Pemecahan Masalah Matematika Siswa di SMPN 1 SP Padang. Thesis UIN Raden Fatah Palembang. http://eprints.radenfatah.ac.id (accessed on 10 July 2018 at $20.30 \mathrm{WIB}$ ) 